\title{
Aplikasi Pengenalan Batu Akik Berbasis Android
}

\author{
Yogiswara Dharma Putra, I Ketut Gede Darma Putra, I Putu Agus Eka Pratama \\ Program Studi Teknologi Informasi Universitas Udayana \\ Bukit Jimbaran, Bali, Indonesia, telp. (0361) 701806 \\ e-mail: yogiswaradputra@gmail.com, ikgdarmaputra@unud.ac.id, eka.pratama@unud.ac.id
}

\begin{abstract}
Abstrak
Batu akik merupakan sebuah mineral alamiah dari prosedur geologi yang memiliki komponen kimiawi. Pemakaian perhiasan yang menggunakan batu akik popular di kalangan masyarakat umum karena keindahan dan keunikannya yang juga menjadi salah satu daya tarik bagi peminat batu akik. Penelitian Aplikasi Pengenalan Batu Akik Berbasis Android merupakan sistem image retrieval berbasis Android yang dirancang mampu memberikan kemudahan bagi peminat batu akik untuk mencari informasi dengan cepat mengenai batu akik, salah satunya adalah untuk mencari jenis-jenis batu akik. Pencarian jenis-jenis batu akik pada aplikasi dilakukan dengan Metode HSV dan YCbCr menggunakan histogram warna untuk mengenali warna, Gabor Filter untuk mengenali tekstur dan perhitungan Euclidean Distance untuk mencari kecocokan dari citra query dengan citra database. Uji coba dan analisa pada fitur warna HSV dan YCbCr menghasilkan akurasi sebesar 60,4\% dan 59,6\%, sedangkan Fitur tekstur Filter Gabor mendapatkan hasil akurasi pada theta 0 derajat sebesar $46,8 \%$, theta 45 derajat sebesar 45,6\%, theta 90 derajat sebesar $45.2 \%$ dan theta 135 derajat sebesar 42,8\%. Kombinasi deteksi Metode HSV menggunakan histogram warna dan Filter Gabor mendapatkan akurasi lebih baik yaitu sebesar $60 \%$ dibandingkan Metode $\mathrm{YCbCr}$ menggunakan histogram warna dan Filter Gabor dengan hasil akurasi sebesar 56\%.
\end{abstract}

Kata Kunci: Histogram Warna, Gabor Filter, Batu Akik, Android, Sistem Image Retrieval

\begin{abstract}
Agate is a natural mineral from geological processes that have chemical components. Wearing a jewelry with this gemstone is popular among the people, because of its beauty and uniqueness, which is interesting for the enthusiasts. This research, Agate Recognition Applications Based on Android, was an Android-based image retrieval system that facilitated the agate enthusiasts to find information about agate quickly, that was identification process of an agate's type. This application identified an agate by using $\mathrm{HSV}$ and $\mathrm{YCbCr}$ method, using color histogram to recognizing color, Gabor Filter to recognizing texture and Euclidean Distance calculation to matching the query image with the database. The testing and analysis on HSV and $\mathrm{YCbCr}$ color features generated accuracy percentage of $60.4 \%$ and $59.6 \%$, while Gabor Filter texture features generated accuracy of $46,8 \%$ on 0 -degree theta, $45,6 \%$ on 45 -degrees theta, $45.2 \%$ on 90 -degrees theta and $42.8 \%$ on 135 -degrees theta. The combination of HSV detection method, color histogram and Gabor Filter generated 60\% better accuracy, while the combination of YCbCr method, color histogram and Gabor Filter generated accuracy of $56 \%$.
\end{abstract}

Keywords: Color Histogram, Gabor Filter, Agate, Android, Image Retrieval System

\section{Pendahuluan}

Batu akik merupakan sebuah mineral alamiah dari prosedur geologi yang memiliki komponen kimiawi [1]. Pemakaian perhiasan yang menggunakan batu akik popular di kalangan masyarakat umum karena keindahan dan keunikannya yang juga menjadi salah satu daya tarik bagi peminat batu akik [2]. Batu akik bukan hanya sebagai penghias pada cincin melainkan bisa dijadikan bandul pada kalung dan dapat memiliki banyak jenis. Harga dari batu akik beraneka ragam dari yang paling murah hingga paling mahal tergantung dari kombinasi warna, bentuk dan teksturnya [3]. Batu akik atau agate merupakan batu yang tercipta karena proses alam yang sangat lama dari pengendapan fosil dan pembentukan mineral yang berpadu menjadi 
sebuah batu akik atau permata. Batu akik mempunyai jenis yang berbagai macam, terkadang sulit menentukan jenis batu akik bagi orang awam [2].

Karakteristik yang dimiliki batu akik pada dasarnya terdapat warna, bentuk dan tekstur. Batu akik dari satu jenis yang sama kemungkinan memiliki tekstur yang berbeda walaupun memiliki warna yang sama, hal ini terjadi karena batu akik setelah diasah menjadi batu cincin dapat memiliki tekstur yang berbeda tetapi tetap memiliki warna yang sama. Batu akik yang sudah diasah menjadi batu cincin dapat memiliki karakteristik khusus pada bagian teksturnya dari satu jenis yang sama [4].

Sistem Image Retrieval berbasis Android adalah suatu sistem penemuan kembali informasi dalam bentuk citra yang mengukur kemiripan antara citra yang tersimpan dalam basis data terhadap citra query yang dimasukkan oleh pengguna menggunakan smartphone Android. Penelitian Aplikasi Pengenalan Batu Akik Berbasis Android menggunakan metode-metode pengolahan citra yang mendukung dalam kinerja aplikasi sebagai sistem Image Retrieval. Metode yang digunakan yaitu Metode HSV dan YCbCr dengan menggunakan histogram warna untuk mengenali warna dan Metode Filter Gabor untuk mengenali tekstur. Aplikasi yang digunakan diharapkan mampu memberikan kemudahan bagi pengguna dalam mengenali jenisjenis batu akik. Aplikasi dirancang memberikan informasi berupa teks yang menampilkan jenis batu akik serta keterangannya kepada pengguna.

\section{Metodologi Penelitian}

Metodologi penelitian merupakan tahapan-tahapan yang digunakan dalam pembuatan dan perancangan dari penelitian yang dibuat. Metodologi penelitian terdiri dari 8 tahapan digunakan dalam perancangan Aplikasi Pengenalan Batu Akik Berbasis Android dapat dilihat pada Gambar 1.

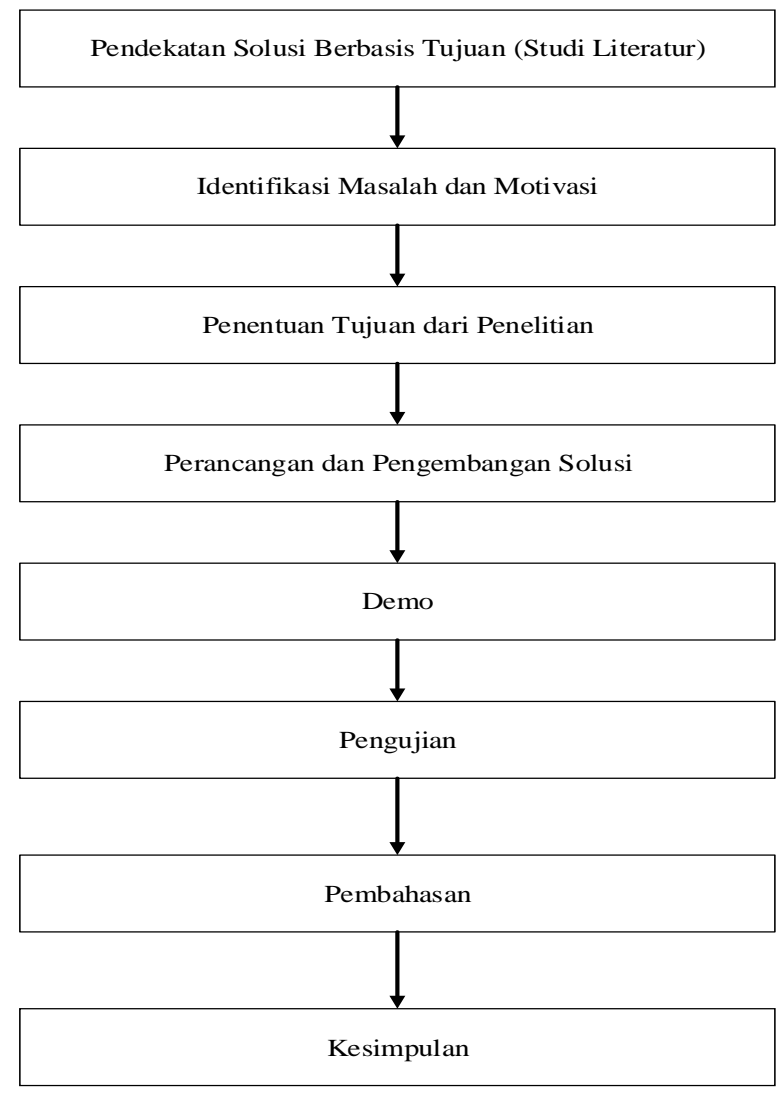

Gambar 1. Metodologi Penelitian

Tahapan-tahapan pada metodologi penelitian yaitu pendekatan solusi berbasis tujuan, penentuan tujuan penelitian, perancangan dan pengembangan solusi, demo, pengujian, pembahasan dan kesimpulan [5]. 


\subsection{Gambaran Umum Aplikasi} Gambar 2.

Gambaran umum dari Aplikasi Pengenalan Batu Akik Berbasis Android dijelaskan pada

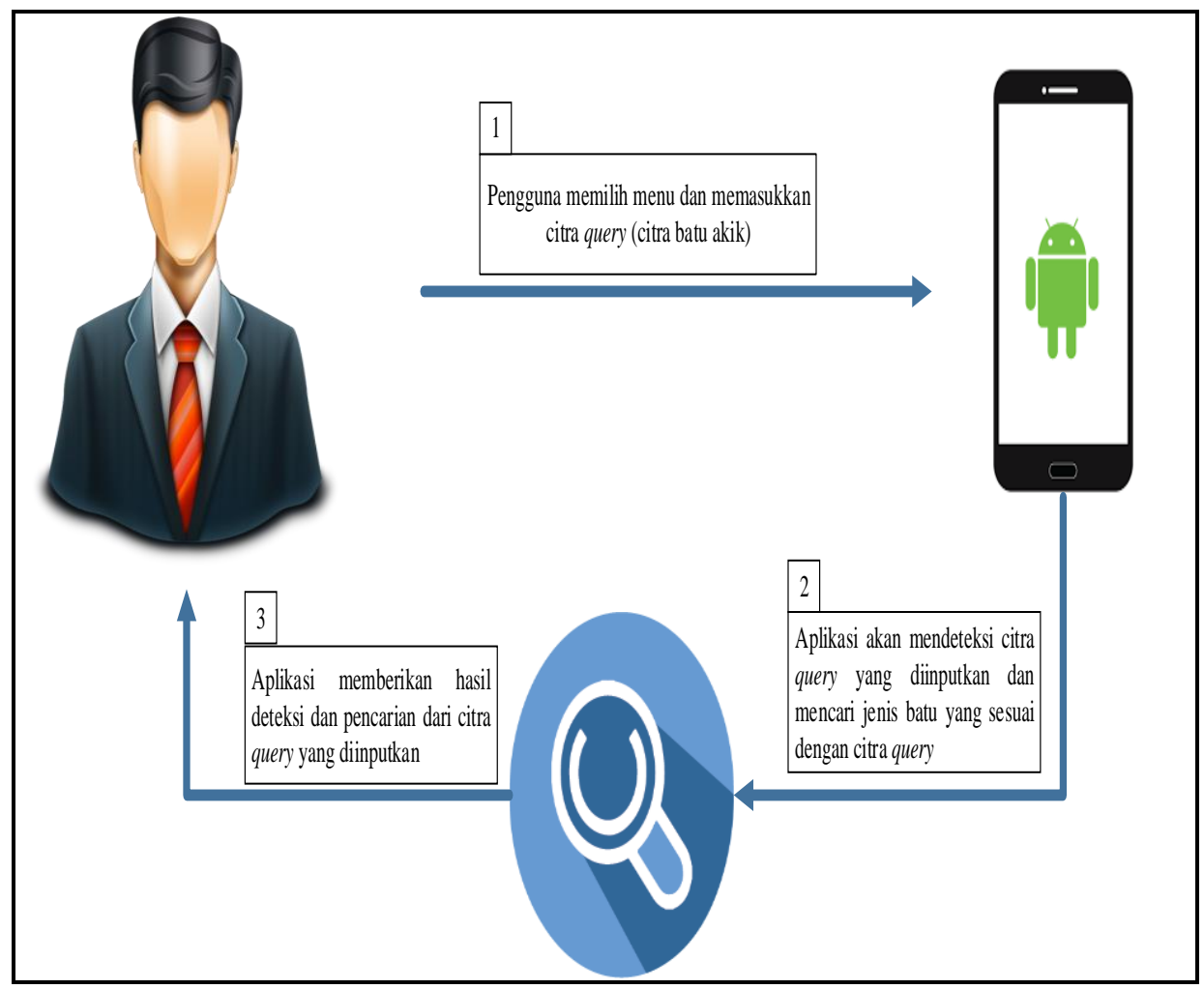

Gambar 2. Gambaran Umum Aplikasi

Aplikasi pengenalan batu akik berbasis android merupakan aplikasi yang didukung dengan teknologi pengolahan citra digital menggunakan Library OpenCV. Aplikasi menggunakan batu akik sebagai objek dan dua metode dalam pemprosesan citra digital. Metode yang digunakan adalah metode ekstrasi ciri warna memakai Metode HSV dan $\mathrm{YCbCr}$ menggunakan histogram warna, serta ekstrasi ciri tekstur memakai Metode Filter Gabor. Ekstrasi ciri digunakan agar dapat mengenali ciri warna dan tekstur dari masing-masing jenis batu akik, setelah mendapatkan fitur warna dan tekstur maka fitur tersebut disimpan ke dalam database SQLite. Metode pengenalan yang digunakan yaitu Metode Euclidean Distance untuk mendapatkan jarak fitur terdekat dari jenis batu akik yang ada pada database SQLite. Aplikasi Pengenalan Batu Akik Berbasis Android memiliki 2 fitur dalam pengambilan citra query yaitu, fitur pertama mendeteksi jenis batu akik dengan mengambil citra melalui kamera smartphone dan fitur kedua mengambil citra melalui gallery smartphone.

\section{Kajian Pustaka}

Kajian pustaka merupakan bahan yang dijadikan sebagai acuan dalam pembuatan penelitian yang teridiri dari State of the Art, Ruang Warna HSV, Ruang Warna YCbCr dan Filter Gabor.

\subsection{State of the Art}

Beberapa penelitian terdahulu yang terkait dalam pengolahan citra digital digunakan sebagai acuan dalam penelitian Aplikasi Pengenalan Batu Akik Berbasis Android, dibahas pada Bagian State of the Art. Penelitian yang berjudul "Herb Recognition Based on Android using OpenCV' membuat sebuah aplikasi mengenai pengenalan tanaman herbal tradisional yang dikembangkan pada Android. Aplikasi dibuat menggunakan metode bentuk, ruas dan keypoint. Bentuk dan ruas dikenali menggunakan metode Invariant Momment sebagai ekstraksi fitur dan City Block Distance sebagai proses perhitungan jarak antar fitur. Metode ORB digunakan untuk mendeteksi keypoint dari tanaman herbal tradisional dan Brute Force Hamming sebagai proses 
perhitungan jarak antar point-point. Pencocokan dilakukan dengan menghitung jarak terpendek antar citra uji dan citra database. Aplikasi menampilkan informasi mengenai tanaman herbal tradisional yang dapat dilakukan dengan mengambil gambar atau foto menggunakan kamera smartphone untuk dapat dikenali melalui aplikasi [6].

Penelitian lainnya yang menggunakan pengolahan citra digital yaitu "Bone Fracture Detection Using OpenCV" yang membuat aplikasi untuk mendeteksi kerusakan tulang menggunakan library OpenCV. Patah tulang adalah kondisi tulang yang mengalami kerusakan integritas tulang yang terputus antara dua tulang yang rawan. Sistem ini menggunakan metode deteksi Canny Edge untuk mendeteksi kerusakan tulang. Hasil dari simulasi sistem adalah untuk membantu menentukan lokasi kerusakan tulang pada gambar x-ray [7].

Penelitian yang berjudul "Sistem Pengenalan Kualitas Ikan Gurame dengan Wavelet, PCA, Histogram HSV dan KNN" juga menggunakan pengolahan citra sebagai proses dalam membuat aplikasi untuk mengenali kualitas dari ikan gurame. Metode yang digunakan yaitu alih ragam wavelet haar dan Principle Component Analysis (PCA) sebagai gabungan 2 Metode ekstraksi fitur sedangkan untuk mengenali jenis induk gurame menggunakan ekstraksi fitur histogram HSV serta proses klasifikasi menggunakan K-Nearest Neighborhood (K-NN) [8]. Aplikasi Pengenalan Batu Akik Berbasis Android memiliki kemiripan penelitian yang membahas pengenalan suatu objek menggunakan pengolahan citra digital, tetapi metode yang digunakan berbeda yaitu Metode HSV dan YCbCr menggunakan histogram warna serta Filter Gabor.

\subsection{Ruang Warna HSV}

Ruang Warna HSV merupakan model warna yang lebih dekat mendeskripsikan warna dari model warna RGB yang mudah diterima oleh mata. Hue mempunyai ukuran nilai antara 0255 yang nilai 0 mewakili nilai spectrum dari warna merah. Saturation adalah proses untuk menambah tingkat kecerahan warna utama yaitu warna hue, jika nilai dari saturation adalah nol maka warna akhir bukan dari warna utama dari hue tetapi warna putih. Value merupakan besar pencahayaan dari warna utama, warna yang memiliki nilai value sampai $100 \%$ maka terlihat sangat cerah atau menjadi putih sedangkan saat warna utama memiliki nilai value $0 \%$ maka terlihat gelap atau menjadi hitam [9].

\subsection{Ruang Warna $\mathrm{YCbCr}$}

$\mathrm{YCbCr}$ merupakan standar internasional bagi pengkodean digital gambar televisi yang didefinisikan di CCIR Recommendation 601. Y merupakan komponen luminance, $\mathrm{Cb}$ adalah warna biru chromatic dan $\mathrm{Cr}$ adalah komponen chrominance warna merah. Monitor Monokrom nilai luminance digunakan untuk merepresentasikan warna RGB, secara psikologis monitor monokrom mewakili intensitas sebuah warna RGB yang diterima oleh mata. Chrominance merepresentasikan corak warna dan saturasi (saturation). Nilai komponen chrominance juga mengindikasikan banyaknya komponen warna biru dan merah pada warna. Retina mata mempunyai dua macam sel yang berfungsi sebagai analis visual yaitu sel yang digunakan untuk penglihatan di waktu siang dan malam hari. Jenis yang pertama hanya menerima corak keabuan mulai dari warna putih terang sampai dengan hitam pekat dan jenis kedua menerima corak warna. Sebuah warna RGB yang diberikan, sel jenis yang pertama mendeteksi tingkat keabuan (gray level) yang serupa dengan nilai luminance-nya, sedangkan sel jenis kedua yang bertanggung jawab terhadap penerimaan corak warna, mendeteksi nilai yang sesuai dengan nilai chrominance-nya YCbCr dapat dihitung dengan menggunakan nilai warna HSV [10].

\subsection{Filter Gabor}

Kemampuan sistem visual manusia dalam membedakan berbagai tekstur didasarkan atas kapabilitas dalam mengidentifikasikan berbagai frekuensi dan orientasi spasial dari tekstur yang diamati. Filter Gabor merupakan salah satu filter yang mampu mensimulasikan karakteristik sistem visual manusia dalam mengisolasi frekuensi dan orientasi tertentu dari citra. Karakteristik sistem visual manusia membuat Filter Gabor sesuai untuk aplikasi pengenalan tekstur dalam computer vision. Fungsi Gabor pertama kali diperkenalkan oleh Denis Gabor sebagai tools untuk deteksi sinyal dalam Derau. Daugman mengembangkan kerja Gabor ke dalam filter dua dimensi. Filter Gabor adalah filter linier yang digunakan dalam pengekstrasian fitur wajah sebagai detektor ciri. Gabor Filter dikenal sebagai detektor ciri yang sukses karena memiliki kemampuan menghilangkan variabilitas yang disebabkan oleh iluminasi kontras dan 
sedikit pergeseran serta deformasi citra, output Filter Gabor telah digunakan dengan sukses untuk pengenalan wajah [11].

\section{Hasil dan Pembahasan}

Hasil dan pembahasan membahas mengenai tampilan dari aplikasi dan analisa uji coba aplikasi yang menghasilkan tingkat akurasi dari aplikasi untuk mengetahui kesesuaian aplikasi yang dibuat.

\subsection{Hasil Tampilan Aplikasi}

Aplikasi Pengenalan Batu Akik Berbasis Android memiliki tampilan utama yang memiliki beberapa menu yang dapat digunakan dalam melakukan interaksi pada aplikasi. Menu-menu yang terdapat pada aplikasi diantaranya menu deteksi, menu tambah data dan menu list data. Menu deteksi merupakan menu untuk melakukan deteksi dari jenis-jenis batu akik, Pengguna dapat memilih jenis deteksi yaitu deteksi dengan HSV atau deteksi dengan YCbCr. Menu tambah data merupakan menu untuk menambah data batu akik ke dalam database. Menu list data merupakan menu untuk menampilkan data jenis batu akik yang sudah tersimpan ke dalam database.

\section{Menu Deteksi}

Menu deteksi ditampilkan ketika pengguna pada tampilan utama memilih menu deteksi yang memiliki dua pilihan menu deteksi yaitu HSV dan YCbCr.

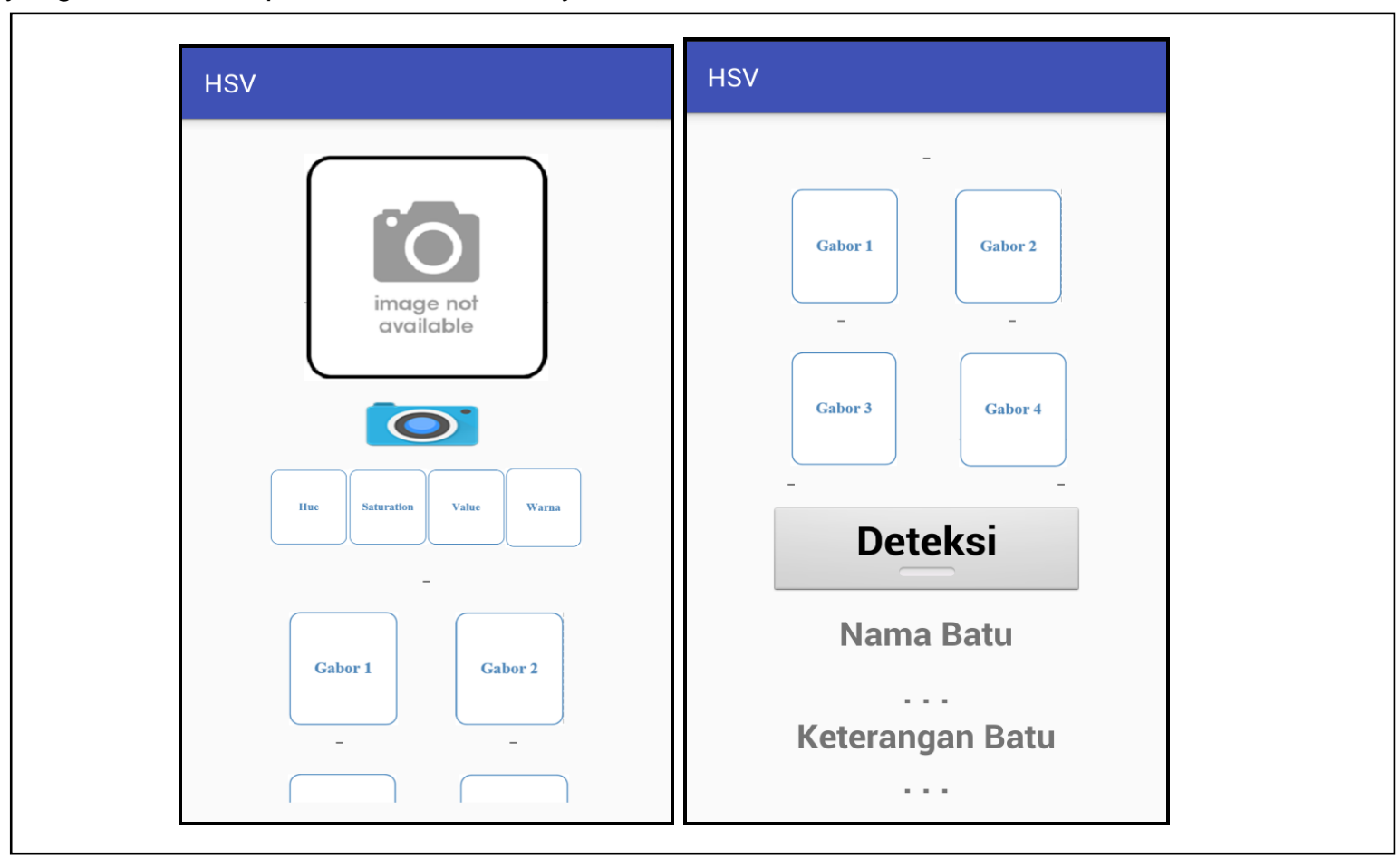

Gambar 3. Tampilan Menu Deteksi HSV

Gambar 3 merupakan tampilan menu deteksi menggunakan Metode HSV, terdapat button untuk melakukan upload citra dan button untuk melakukan pengenalan. Tampilan menu deteksi HSV menampilkan hasil ekstrasi fitur dari citra yang dimasukkan yaitu fitur warna dan tekstur serta menampilkan hasil pengenalan berupa nama dan keterangan dari batu akik. 


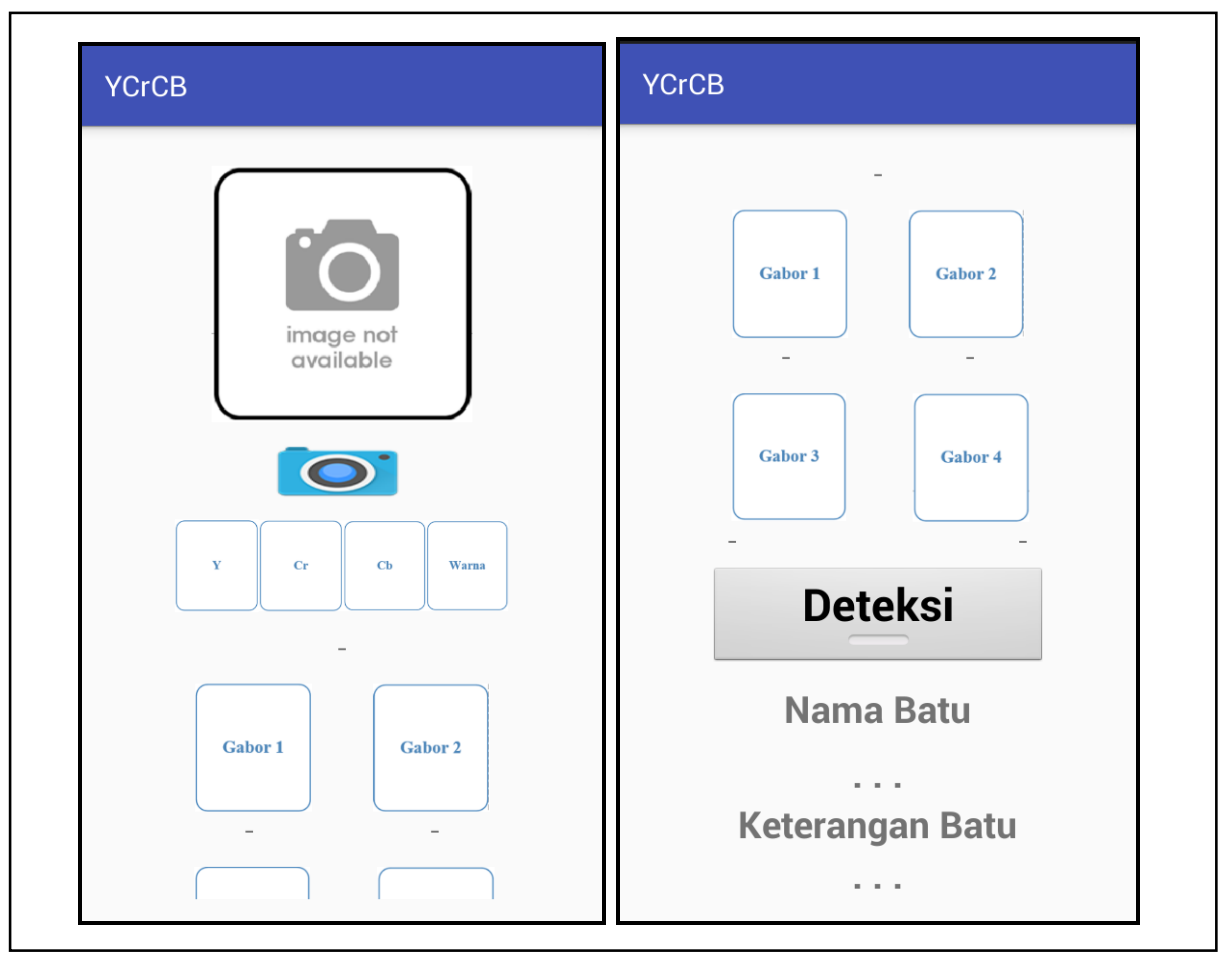

Gambar 4. Tampilan Menu Deteksi YCbCr

Gambar 4 merupakan tampilan menu deteksi menggunakan Metode $\mathrm{YCbCr}$ yang terdapat button untuk melakukan upload citra dan button untuk melakukan pengenalan. Tampilan menu deteksi $\mathrm{YCbCr}$ menampilkan hasil ekstrasi fitur dari citra yang dimasukkan yaitu fitur warna dan tekstur serta menampilkan hasil pengenalan berupa nama dan keterangan dari batu akik.

2. Menu Tambah Data

Menu tambah data ditampilkan ketika pengguna pada tampilan utama memilih menu tambah data.

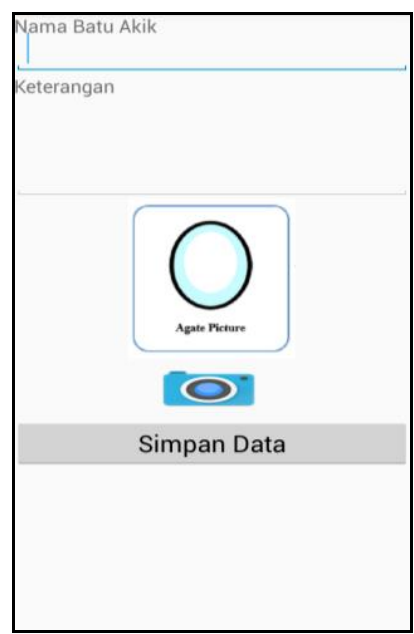

Gambar 5. Tampilan Menu Tambah Data

Gambar 5 merupakan tampilan yang berfungsi untuk menambahkan data ke dalam database, data yang disimpan berupa nama, keterangan, gambar dan hasil pengolahan dari metode yang digunakan dari citra batu akik. Data manipulasi disimpan dalam database sqlite. 


\section{Menu List Data}

Menu list data ditampilkan ketika pengguna pada tampilan utama memilih menu list data untuk melihat data dari batu akik.

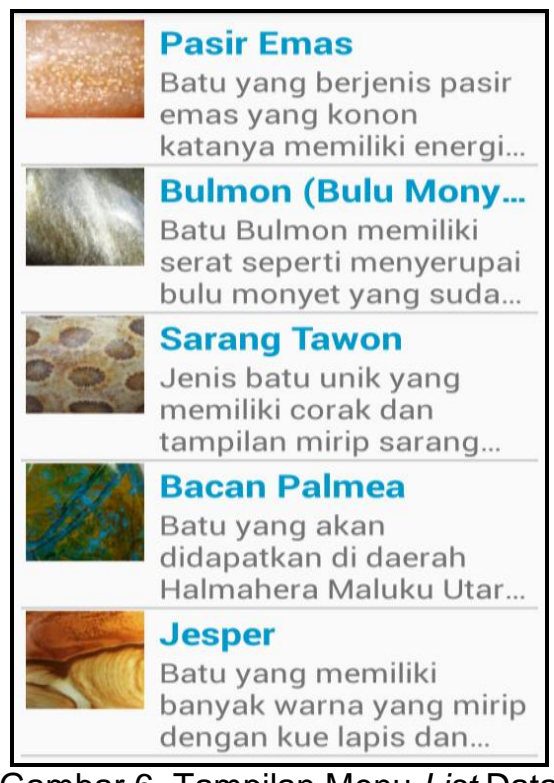

Gambar 6 merupakan tampilan data yang tersimpan di dalam database. Data yang ditampilkan dari citra batu akik berupa nama, keterangan dan citra dari batu akik.

\subsection{Analisa}

Pengujian dilakukan untuk mengetahui jenis-jenis batu akik yang dikenali berdasarkan kombinasi metode warna dan tekstur. Kedua metode pengenalan menentukan batu akik dapat dikenali atau tidak menggunakan perhitungan jarak fitur antara citra yang dimasukkan dengan citra yang tersimpan di dalam database.

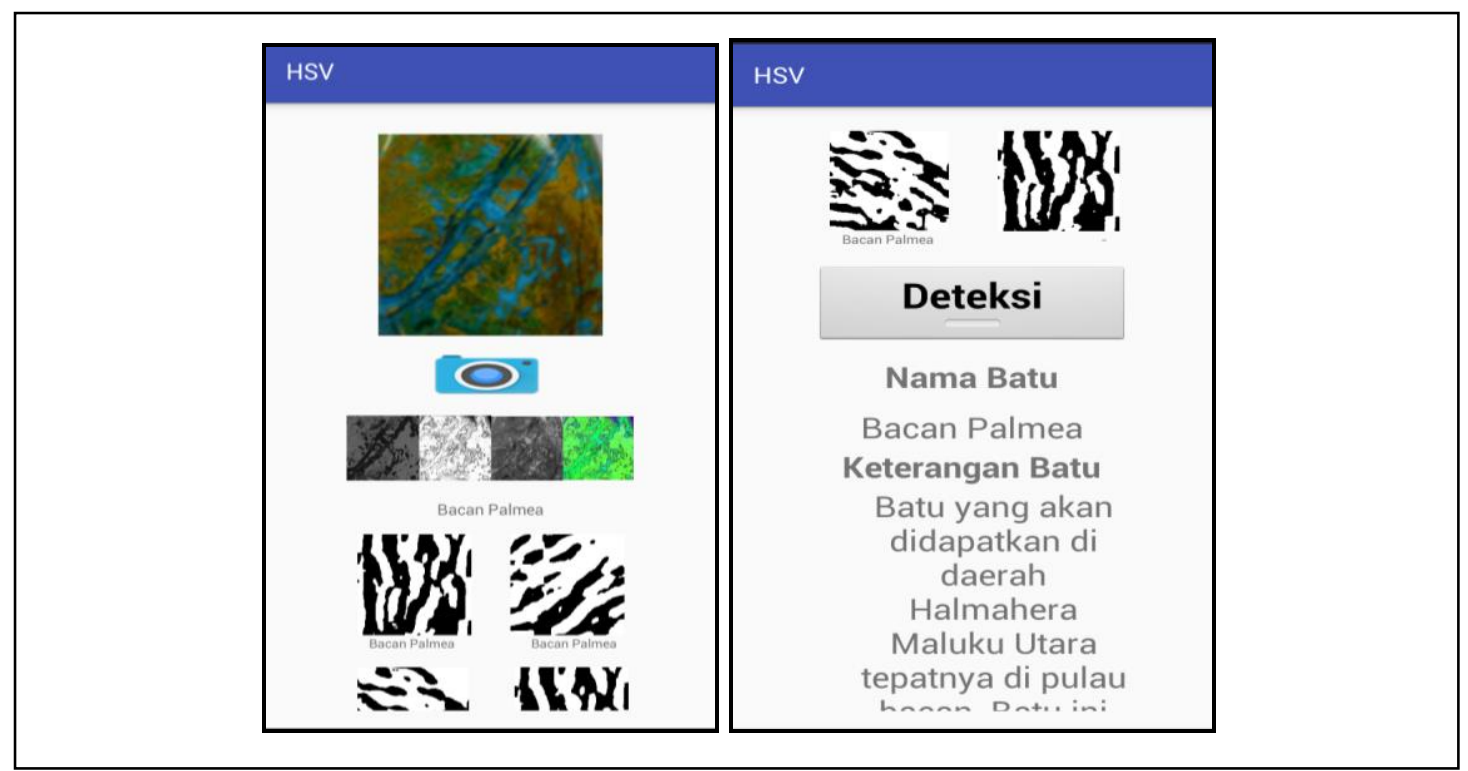

Gambar 7. Uji Coba Ekstraksi Fitur Warna dan Tekstur

Gambar 7 merupakan hasil ekstrasi kedua fitur yang digunakan yaitu ekstrasi fitur warna dan tekstur dari citra query yang dimasukkan. Metode histogram warna didapat dengan mengubah nilai RGB menjadi HSV, kemudian dari ruang warna HSV membandingkan nilai yang 
didapatkan dengan memasukkan nilai hasil citra fitur dominan atau sering muncul pada database. Metode Gabor Filter didapat dengan mengubah nilai RGB menjadi binary kemudian dengan menentukan parameter theta, lambda, sigma, gamma dan psi yang memiliki ukuran tapis $31 \times 31$.

Analisa dilakukan terhadap Aplikasi Pengenalan Batu Akik Berbasis Android untuk mengetahui proses keberhasilan dan kegagalan sistem dalam memproses metode yang digunakan. Metode yang dianalisa yaitu Metode HSV dan $\mathrm{YCbCr}$ menggunakan histogram warna dan Metode Filter Gabor, kemudian pencocokan citra dari kedua metode tersebut menggunakan 50 jenis data batu akik yang masing-masing jenis memiliki 5 citra data uji.

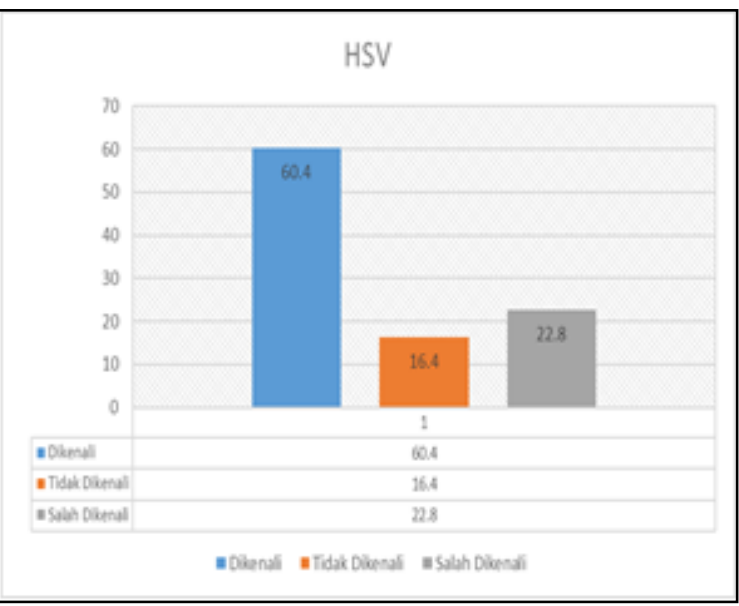

(a)

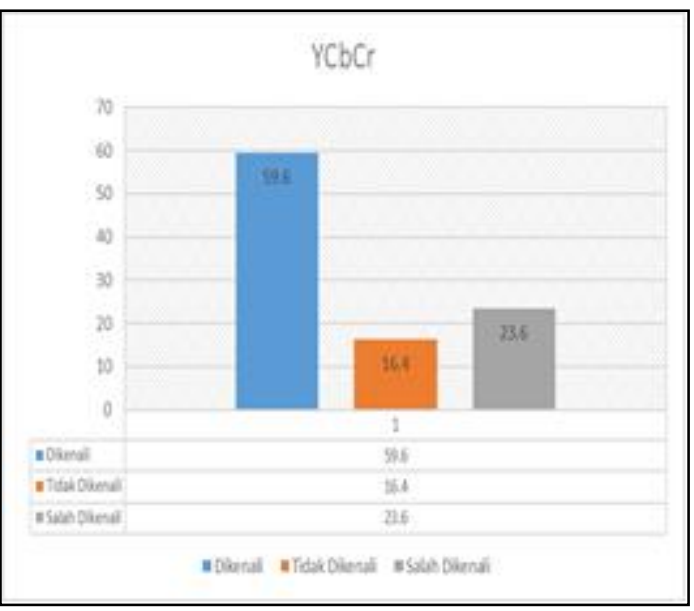

(b)

Gambar 8. (a) Grafik Persentase Warna HSV Menggunakan Histogram Warna, (b) Grafik Persentase YCbCr Menggunakan Histogram Warna

Gambar 8 merupakan grafik hasil persentase Metode HSV dan YCbCr menggunakan histogram warna. Hasil menunjukkan akurasi batu akik yang dikenali sebesar $60,4 \%$, tidak dikenali sebesar 26,4\% dan salah dikenali sebesar 22,8\% untuk Metode HSV, sedangkan Metode YCbCr menunjukkan hasil akurasi batu akik yang dikenali sebesar $59,6 \%$, tidak dikenali sebesar $16,4 \%$ dan salah dikenali sebesar $23,6 \%$.

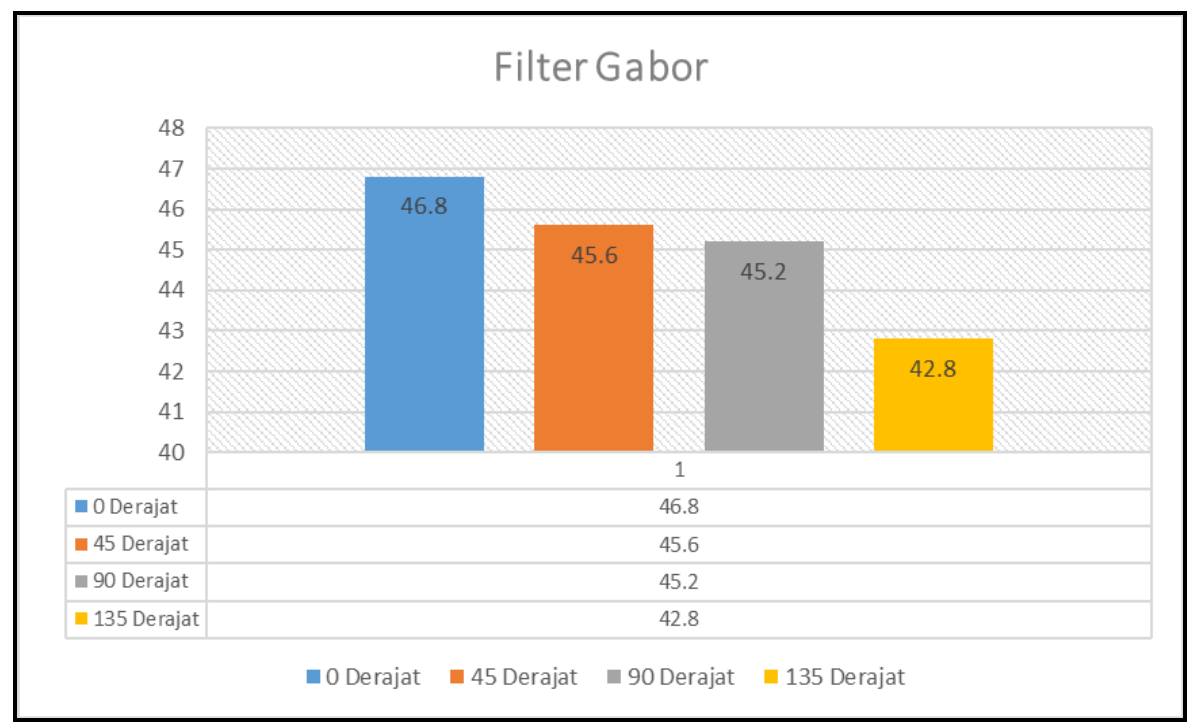

Gambar 9. Grafik Persentase Tekstur Filter Gabor 
Gambar 9 merupakan grafik hasil persentase Metode Filter Gabor yang menunjukkan hasil akurasi sebesar $46,8 \%$ pada theta 0 derajat, $45,6 \%$ pada theta 45 derajat, $45,2 \%$ pada theta 90 derajat dan $42,8 \%$ pada theta 135 derajat.

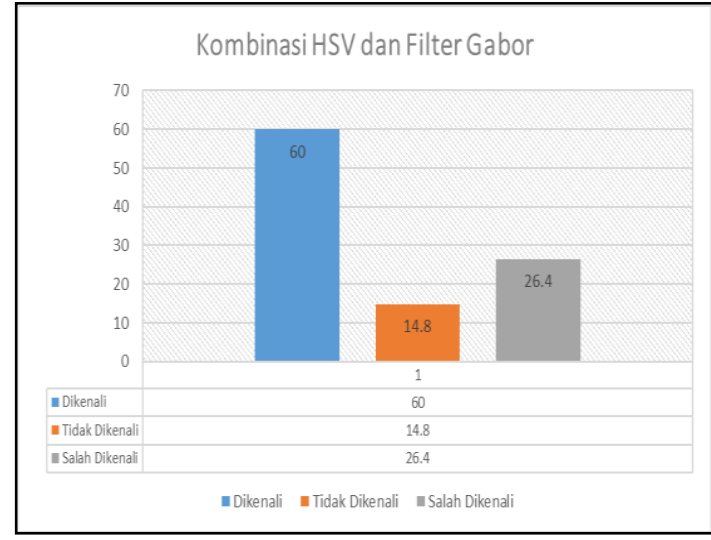

(a)

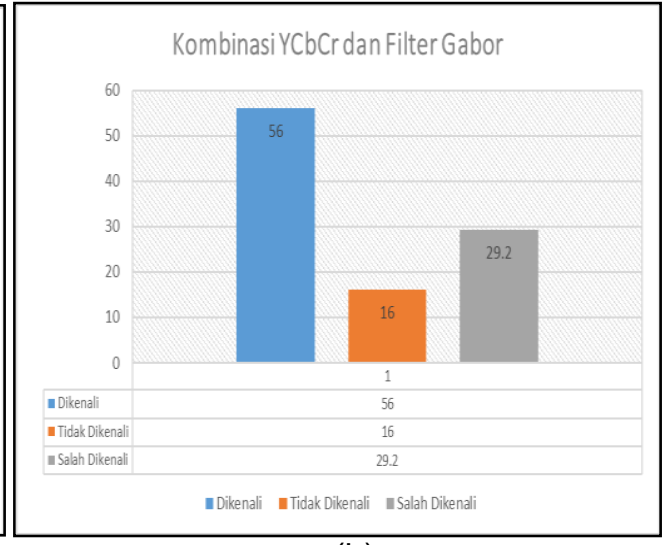

(b)

Gambar 10. (a) Grafik Persentase Kombinasi HSV Menggunakan Histogram Warna dan Filter Gabor, (b) Grafik Persentase Kombinasi YCbCr Menggunakan Histogram Warna dan Filter Gabor

Gambar 10 merupakan grafik hasil persentase kombinasi antara Metode HSV dan $\mathrm{YCbCr}$ menggunakan histogram warna dan Metode Filter Gabor. Hasil pengujian menunjukkan akurasi batu akik yang dikenali sebesar $60 \%$, tidak dikenali sebesar $14,8 \%$ dan salah dikenali sebesar 26,4\% untuk kombinasi HSV. Hasil pengujian $\mathrm{YCbCr}$ menunjukkan akurasi batu akik yang dikenali sebesar $56 \%$, tidak dikenali sebesar $16 \%$ dan salah dikenali sebesar $29,2 \%$. Tingkat akurasi pengenalan batu akik pada kombinasi Metode HSV menggunakan histogram warna dan Metode Filter Gabor memiliki akurasi lebih baik dibandingkan dengan penggunaan kombinasi Metode $\mathrm{YCbCr}$ menggunakan histogram warna dan Metode Filter Gabor.

\section{Kesimpulan}

Aplikasi Pengenalan Batu Akik Berbasis Android adalah aplikasi yang digunakan untuk mencari informasi dari sekumpulan data citra yang disimpan dan membandingkan antara citra query dengan citra pada database. Tujuan aplikasi yaitu untuk mengenali jenis-jenis batu akik berdasarkan warna dan tekstur. Uji coba dan analisa dilakukan menggunakan 50 jenis citra data batu akik dengan setiap batu akik memiliki 5 data citra. Hasil pengujian menunjukkan akurasi sebesar $60,4 \%$ dan $59,6 \%$ untuk fitur warna HSV dan $\mathrm{YCbCr}$, sedangkan fitur tekstur Filter Gabor memperoleh akurasi sebesar $46,8 \%$ pada theta 0 derajat, $45,6 \%$ pada theta 45 derajat, $45,2 \%$ pada theta 90 derajat dan $42,8 \%$ pada theta 135 derajat. Kombinasi deteksi Metode HSV menggunakan histogram warna dan Filter Gabor menghasilkan akurasi yang lebih baik yaitu sebesar $60 \%$ dikenali, $14,8 \%$ tidak dikenali dan $26,4 \%$ salah dikenali dibandingkan Metode YCbCr menggunakan histogram warna dan Filter Gabor dengan hasil akurasi sebesar $56 \%$ dikenali, $16 \%$ tidak dikenali dan $29,2 \%$ salah dikenali.

\section{Daftar Pustaka}

[1] R. Hidayat, "Implementasi Penggabungan Metode Fitur Ciri Orde 1 dan Fitur Ciri Orde 2 pada Citra untuk Pengklasifikasian Jenis Batu Akik," Jurnal IImu Komputer dan Informatika., vol. 2, no.1, pp. 5-24, 2009.

[2] Yagus Triana HS, "Batu Akik Sebagai Budaya Populer," Artefak, vol. 4, no. 1, pp. 1-8, 2017.

[3] M. S. Backtiar and A. D. Supriatna, "Pengembangan Sistem Informasi Penjualan Batu Akik," Algoritma., vol. 12 no. 1, pp. 1-8, 2014.

[4] N. P. G. Widhi, "Fenomena Komunikasi Komunitas Batu Akik di Kota Pekanbaru (Studi Fenomenologi pada Anggota Komunitas Asosiasi Permata Riau (APR))," Jurnal Online Mahasiswa Fakultas IImu Sosial dan IImu Politik., vol. 3, no. 2, pp. 1-13, 2016. 
[5] I. P. A. E. Pratama, Sistem Informasi dan Implementasinya Berbasis Open Source, Bandung: Bandung Informatika, 2014.

[6] I. W. Agus Suryawibawa, I. K. Gede Darma Putra, and N. K. Ayu Wirdiani, "Herbs Recognition Based on Android Using OpenCV," International Journal Image Graphic Signal Process., vol. 7, no. 2, pp. 1-7, 2015.

[7] S. F. Kurniawan, I. K. G. D. Putra, and A. K. O. Sudana, "Bone Fracture Detection Using OpenCV," Journal Theory Applicatioan Information Technology., vol. 64, no. 1, 2014.

[8] F. Astutik, "Sistem Pengenalan Kualitas Ikan Gurame dengan Wavelete, PCA, Histogram HSV dan KNN," Lontar Komputer., vol. 4, no. 2, pp. 336-346, 2013.

[9] I. P. P. Andika, P. A. Bayupati, and N. K. A. Wirdiani, "Rancang Bangun Aplikasi Pendeteksi Tipe dan Nilai Resistor Berbasis Android," Lontar Komputer., vol. 6, no. 1, pp. 529-540, 2015.

[10] P. P. Adikara, A. Rahman, and E. Santosa, "Pencarian Ruang Warna Kulit Manusia Berdasarkan Nilai Karakteristik ( $\Lambda$ ) Matrik Window Citra," Jurnal Teknologi Informasi dan IImu Komputer., vol. 1, no. 9, pp. 29-33, 2014.

[11] A. S. Arwanda, "Content Based Image Retrieval Batik Tradisional Yogyakarta dengan Ekstrasi Ciri Berdasarkan Tekstur Filter Gabor Wavelets 2D Skripsi Content Based Image Retrieval dengan Ekstrasi Ciri Berdasarkan Tekstur Filter Gabor Wavelets 2D," Technology of Information and Communication., vol. 1, no. 3, pp. 12-18, 2009. 